\title{
Accounting Internships: A Student-Driven Approach
}

Richard Cummings, (E-mail: CummingR@uww.edu), University of Wisconsin, Whitewater William S. Tataman, University of Wisconsin, Whitewater

\begin{abstract}
The battle for talent is fought over interns and not full-time hires according to the CPA Practice Management Forum (2005). Albrecht and Sacks $(2000,55)$ report that this internship learning experience needs to be carefully managed between the school and the firm. The purpose of this paper is to provide accounting educators with a model to effectively manage an internship program. Specifically this model will provide a unique "student driven" matching of students to employers in the internship process and an effective assessment for this process.
\end{abstract}

\section{INTRODUCTION}

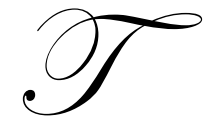

he Albrecht and Sacks $(2000,55)$ survey of 783 accounting professionals and educators indicated that internships are the best out-of-classroom learning activity. Accounting educators ranked the three to four month internships with companies twice as high as the second place field study projects with real companies. Accounting professionals were close to accounting educators in their assessment, ranking the internships 95\% higher than the second place field study projects. Albrecht and Sacks $(2000,55)$ heard frequently from respondents that the internship learning experience needs to be carefully managed between the school and the firm. Especially, students need to know that they will be evaluated by the firm and the school. The purpose of this paper is to provide accounting educators with a model to effectively manage an internship program. Specifically this model will provide a unique "student driven" matching of students to employers in the internship process and an effective assessment for this process.

The accounting literature on internships typically begins with the AAA Committee on Internship Programs (1952) which described the benefit of internships as exposing students to accounting techniques and elements of the business world not commonly found in the classroom. Through this exposure students would have a better perspective of future classroom experiences after they returned to the classroom. The AAA Committee on Faculty Residency and Internship Programs (1955) focused on the internship benefit increasing student motivation for accounting topics after the internship experience. Lowe (1965) and Koehler (1974) have been credited with reporting that internships had "clarified points of theory and meaningfulness of some courses and accordingly deserved the granting of credit" (Knechel and Snowball, 1987).

Empirical studies have primarily studied the issue of post-internship student performance. Knechel and Snowball (1987) found that student performance in post-internship courses were not significantly different between interns and non-interns. They did find in the auditing course the performance of interns was significantly better than non-interns. Siegel and Rigsby (1988) looked beyond the college experience by examining supervisor annual performance evaluations and promotion rates for interns versus non-interns for the first three years of post-graduate employment. These researchers found a significant difference in performance evaluations and promotion rates for interns versus non-interns.

English and Koeppen (1993) extended the Knechel and Snowball (1987) research, which was primarily audit positions with public accounting firms, to private, public, and nonprofit firms in the accounting positions of audit, cost, financial, systems, and tax. English and Koeppen (1993) found that internship students performed significantly better than non-internship students in accounting courses and GPA after their internship experience. 
The battle for talent is fought over interns and not full-time hires according to the CPA Practice Management Forum (2005). Whether interns serve as campus emissaries (Lauber et al..., 2004) or a pipeline to attract the top one percent of talent (Spolsky, 2007) companies with the most successful internship programs create learning opportunities (Thilmany, 2007) where firms receive maximum benefit through active involvement with the schools by effectively marketing themselves to students and faculty (Schmutte, 1985).

This paper examines the role of the employer and student in the internship relationship. Traditionally this role has modeled the free enterprise system or an employer-driven model where employers try to select the best talent from each university. They do this primarily by identifying students who would make good future employees and focusing their efforts on recruiting such candidates. As competition enters this model employers are forced to recruit earlier and earlier to get that candidate before other competing employers. This model has even seen some employers recruiting students before they have even taken their first college course in accounting. This phenomenon begs the question of what criteria employers and students use to make career decisions at such an early time in the student's academic career.

Conversely, the student driven approach is a model where the student is given the first priority of picking an internship employer among many employers. This involves the university becoming involved in the internship relationship by setting guidelines on student and employer expectations. The major guidelines include that internship offers to students are only through the college internship course process. This model benefits employers by providing all employers a level playing field in which to recruit internship candidates. Students benefit by interviewing with many firms. The university benefits by having more student interns being placed while building a relationship with employers: for future internships, classroom visits, Beta Alpha Psi presentations, scholarship sponsorships, faculty internships, and building sponsorships. Illustrated below is the student driven internship model that generated 95 internship positions by 32 employers for the 2007 spring semester.

\section{STUDENT DRIVEN ACCOUNTING INTERNSHIP MODEL}

\section{Creating The Level Playing Field For Students And Employers}

Students

The first stage of providing students with a perspective of the internship program happens almost a year before their senior-level internship will take place. The Accounting Department holds two mandatory meetings in the spring semester of their junior year for all students who plan to participate in next spring's internship program. The internship program is described as a 6 credit hour course that students will enroll in for the next spring semester. The process of preparing resumes, researching companies, scheduling internship interviews, internship pay, and course requirements are just a few items listed in the sample important dates section of their syllabus (see Figure 1).

\section{Figure 1 \\ Syllabus -Sample Important Dates}

$\begin{array}{ll}\bullet & 8 / 1 / 06 \\ \bullet & 8 / 21 / 06 \\ \text { - } & 9 / 12 / 06 \\ \text { - } & 9 / 18 / 06 \\ \text { - } & 9 / 29 / 06 \\ \text { - } & 10 / 9 / 06 \\ & 10 / 30 / 06- \\ \text { - } & 11 / 17 / 06 \\ \text { - } & 11 / 10 / 06 \\ \text { - } & 12 / 5 / 06 \\ & 4 / 20 / 07\end{array}$

\author{
Must be registered at Career Services \\ On-line sign-up for interviews with Career Services \\ Mandatory meeting- Resume and Mock Interviews \\ Interviews begin \\ Students rankings due. DEADLINE 5:00 p.m. Email or turn in list \\ TENTATIVE-Matching process complete. Students emailed list of matches \\ Register for ACCOUNT 493, Section 1 or 2 (I will let you know \\ which section to use) Spring 2007 \\ Internship paper \#1 -Interviewing Process \\ Mandatory meeting On Professionalism and what makes a good intern \\ Internship paper \#2 Internship Experience
}


The two required spring meetings a year before the internship are held two weeks apart. This allows students to think about the internship and to ask more specific questions in the second meeting.

The internship coordinator offers resume and mock interview help. Half the students use this help during the summer before the internships. Another one-third of the students take advantage of this help before the fall internship interviews.

Employers

Employers are very much interested in a transparent internship process. A process where every employer is treated the same and has the same access to students -- a level playing field -- provides integrity to the internship program. Accordingly, the internship coordinator communicates year-round to employers in the following ways.

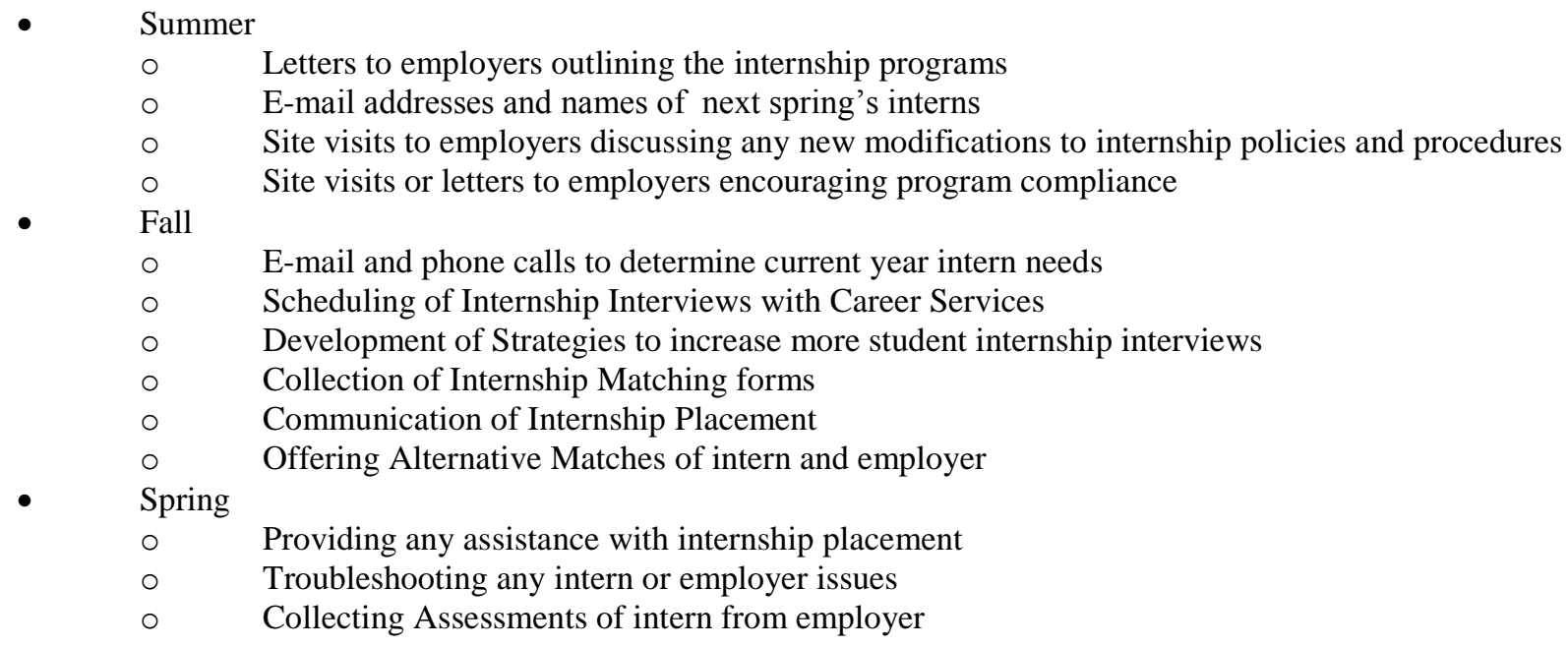

\section{The Selection Process}

Students

Students may use some of the following criteria to select a firm for an internship interview:

- $\quad$ Previous e-mail from the firm inviting them to interview with them

- $\quad$ Student Internship Experience Paper on all firms from previous year

- $\quad$ Research about the firm

- Information from previous year interns

- $\quad$ Site visit or experience with the firm

Students sign up on-line with Career Services to schedule their internship interview times with selected employers. They attend the interviews and fill-out and submit the Internship Matching Form- Student (see Figure 2). Notice that the students weight their choices to indicate how strong their choices are for first or second choice.

Employers

Since all employers are provided with the e-mail addresses of eligible interns they may contact students for resume and recruiting activities with the firm. Employers who make Beta Alpha Psi presentations before the intern interview day in mid-September may contact their potential interns while they are on campus. Any offers to students for internship positions must take place in the internship interviewing and matching process. 
Employers use Internship Matching Form- Firm (see Figure 3) that allows for grouping of candidates to top choices, strong candidates, acceptable and unacceptable. This grouping allows for greater flexibility in matching students than if an employer used a numeric ranking system.

Figure 2

Internship Matching Form - Student

\begin{tabular}{|l|}
\hline Student Name: \\
\hline Phone: \\
\hline Email: \\
\hline
\end{tabular}

Instructions: Please use this form to communicate your internship employer preferences. State your first, second, third choice, and so on (include name and city) and allocate 50 points to indicate your strength of preference. You may also provide a short summary statement that conveys your preference and wishes as simply and clearly as possible.

\begin{tabular}{|l|l|l|l|}
\hline Preference & Points & Name and City & Comments \\
\hline $1^{\text {st }}$ choice & & & \\
\hline $2^{\text {nd }}$ choice & & & \\
\hline $3^{\text {rd }}$ choice & & & \\
\hline $4^{\text {th }}$ choice & & & \\
\hline
\end{tabular}

Please note any other comments you feel may be helpful for the matching process (Used with permission from Ann O'Brien, University of Wisconsin-Madison)

Figure 3

Internship Matching Form - Firm

\begin{tabular}{|l|l|}
\hline Firm Name: & Contact Name: \\
\hline Office Location: & Contact Phone: \\
\hline \# of Positions Available: & Contact Email: \\
\hline
\end{tabular}

\section{Rankings:}

Top Choices

These interns are at the top of your list. You would make offers to all of these interns.

\section{Strong Candidates}

These interns are strong candidates that you would like to have as interns if you cannot fill all of your positions with the candidates you included in the top category.

\section{Acceptable with reservations}

These interns are acceptable but you have some reservations. You would be willing to take these interns to help achieve the educational goals of the program. 


\section{Unacceptable}

You do not want to hire these interns. You have significant reservations about their ability to succeed in your firm and prefer not to have them allocated to you.

(Used with permission from Ann O’Brien, University of Wisconsin-Madison)

\section{The Matching Process}

The matching process in theory is quite simple. Students rankings of firms are given the first priority when matching the intern with the employer. This is the main reason this approach is called a student-driven approach The student's first choice is matched to the firm's top choice. After all student's first choice and firm's tops choice are matched the remaining interns have their second choice and firm's top choice matched. The next match is the student's second choice and the firm's top choice, strong or acceptable choice. An Excel spreadsheet is very helpful in aligning the student and firm selections

The selections that the student and firm make are confidential. After students have selected the firms where they were listed as acceptable or better the internships coordinator contacts the firms who did not get their desired level of interns. The coordinator then discusses a possible match with other candidates. This process is all completed by the time the official matches are released to the students and employers.

\section{Assessment}

Students

Students assess their internship experience in three different ways. In the first paper they do after the interviewing process, but before the actual internship experience, students reflect on the interviewing process. Specifically they are asked to address:

- $\quad$ Preparation for interviews - How did you go about preparing; what sources did you use; did you meet with firm representatives in advance; how did you research firms; did you do mock interviews; how did you prepare your resume.

- $\quad$ The interview itself - How many firms did you interview with; how did you choose which ones to interview with; what types of interviewing styles were utilized; were you prepared for the interviews; did they get easier or tougher as you did more of them; how do you feel you did during the process; what, if anything, would you do differently the next time you interview.

- $\quad$ Ranking the firms - What criteria did you use; how did you go about the process; how difficult was it to make the decision.

- $\quad$ Overall experience - Summarize the overall experience; what did you enjoy or not enjoy about it; what areas of the process would you change, if any, if you were the Internship Director; which areas would you emphasize; what advice would you give future participants.

This process allows the students to assess their own interviewing skills while looking forward to see what improvements could be made to improve the process for next year's interns.

In the second paper they describe their internship experience. This provides a document for future interns to read before they sign-up for an interview with a firm. The intern is asked to share information on:

- $\quad$ The transition - Relay your personal experiences in transitioning from school to your internship positing. Discuss lodging, roommates, commuting, clothes, and initial office experiences and training. Also indicate if the transition was smooth or if complications developed. 
- $\quad$ The learning experience - Relay your personal experience in actually performing the work. Incorporate what you learned from various work experiences. Comment on your personal growth, improvements in your communication skills and development of people skills. Indicate how you learned to interact with clients, supervisors and co-workers. Relate what you have learned in classroom settings to what you experienced in your internships.

- $\quad$ Summarize the experience - Summarize what you learned from the experience. Comment on any aspects that will benefit you in the future, both in school and your professional career. Indicate what you liked and disliked about the experience, and how this has helped you make decisions on the type of employment you will seek upon graduation. Also indicate any other items that you feel need to be addressed.

The third student assessment of the interview process is the Student Internship Survey (see Figure 4). This survey is completed by the student after the internship experience. The focus of this survey is to determine what the student actually did on the internship.

Important questions focus on whether the student received an offer of full-time employment upon graduation from the employer. If an offer has been extended the student is asked to indicate whether he/she has accepted the offer.

\section{Employer}

Employers assess the student intern by using the Employer Accounting Internship Evaluation Form (see Figure 5). Specifically employers are asked if the student intern met or exceeded their expectations for the following eight criteria:

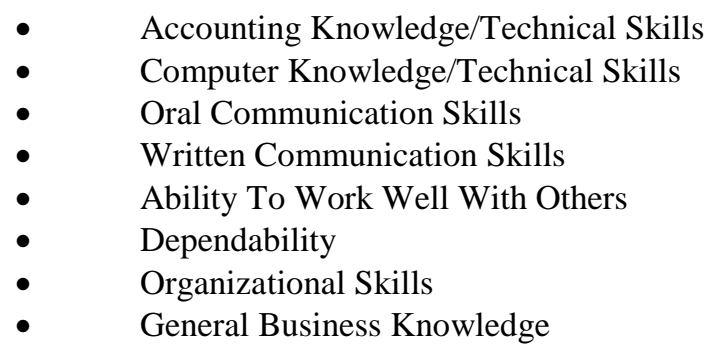

This information is very helpful in assessment of the internship program and the accounting program

Figure 4

Student Internship Survey

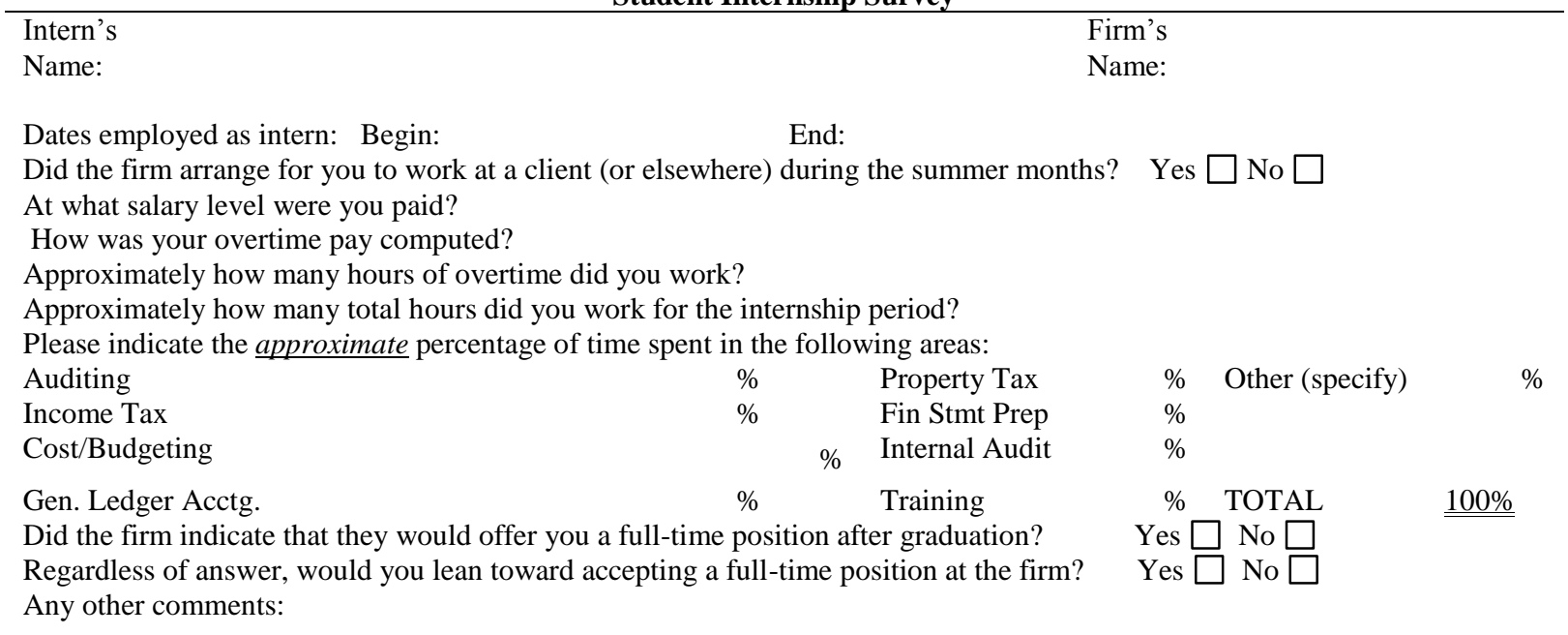


Figure 5

Employer Accounting Internship Evaluation Form

Name of Intern:

Company/Firm Name:

Name of Evaluator:

Use the following scale to evaluate the intern. Check one of the three responses for each area.

$\mathbf{E E}=$ Exceeded Expectations $\quad \mathbf{M E}=$ Met Expectations $\quad \mathbf{N I}=$ Needs Improvement

Accounting Knowledge/Technical Skills

Comments:

Computer Knowledge/Technical Skills

Comments:

Oral Communication Skills

Comments:

Written Communication Skills

Comments:

Ability to Work Well With Others

Comments:
Dependability/Professionalism

Comments:

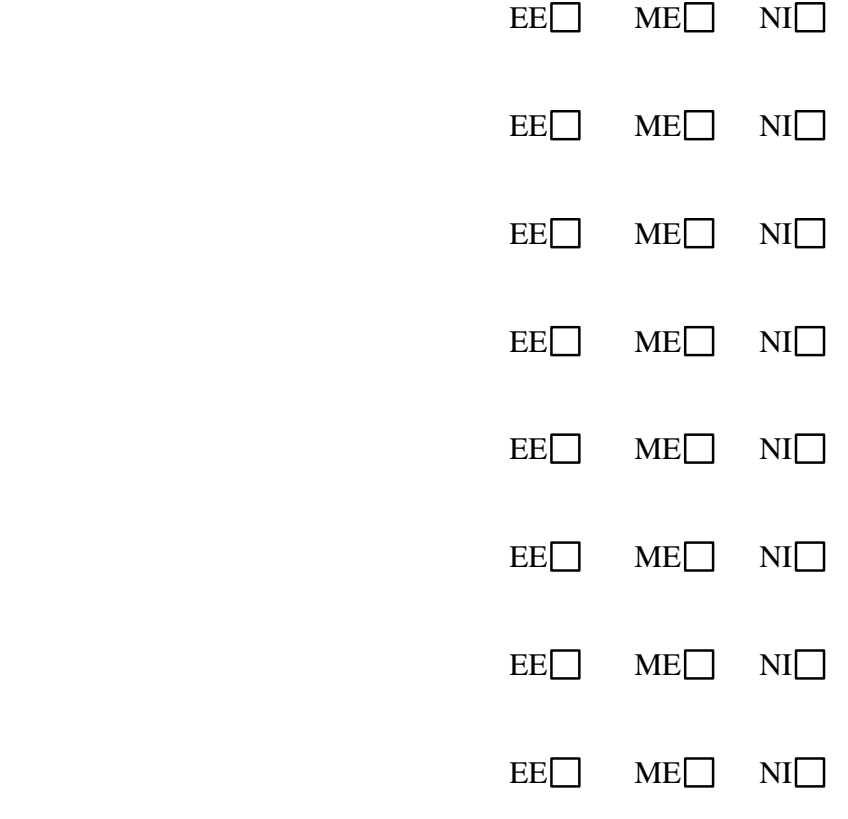

Organizational Skills

Comments:

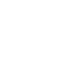




\section{Results from UW-Whitewater- Spring 2007}

Representative data from the University of Wisconsin- Whitewater are illustrated below to show the effectiveness of a student-driven internship program.

Students

The Interview Process Paper- Selected Quotes:

Over this past summer I spent a lot of time reading intern papers. Doing this gave me a real good idea of the firms that I thought that I would be interested in. I would say that I read almost all of the papers from the past year and many papers from the year before that to get a better understanding of a few companies.

My overall experience with the accounting internship program has been enjoyable. I feel that the program is well run and it makes the stressful and nerve-racking time of interviewing much more manageable.

Finally the interviews were over which was great but now I have to rank the firms. This was a very difficult decision for me because I knew that I could possibly be making the biggest decision of my life. I had about four firms that I would be really happy to work for but I didn't know how I was going to narrow it down from there. One of the most important factors for me was the work environment. I wanted to be able to work with people that have fun and are easy to get to know. My other main factor was the location.

The Internship Experience Paper- Selected Quotes:

Given sound goals and a vision for what I wanted out of the internship it was easy for me to transition from the school life to the working world. If there was anything that I found difficult it was the lack of outside socializing and limited free time. I had to schedule everything, from workouts to time with friends and family. I found myself scheduling lunches with friends weeks in advance and plotting out how much free time I would have every week in order to keep from burning out and staying focused on getting my work down. If there is any key advice I can give here it is to stay organized and schedule as much as you can.

Overall, I had a great experience with the internship. It took me a while to feel like I was a part of the crew, partly because of my own shyness, but before I knew it, I was a part of the team, having pranks pulled on me and pulling pranks on other people. The people at ( ) were absolutely awesome and I had a lot of fun working with them. I think that is the key to making any job enjoyable. Another thing I was looking for from the internship was to find my place in a firm. Lucky for me, that happened during my internship.

Overall, the internship experience was great for me. It allowed me to try an area of accounting that I was not sure I would like- I ended up enjoying it very much. I worked hard, learned a lot, asked many questions, and made some great friendships for the future. I was offered full-time employment for the fall of 2008 and I accepted and signed the letter Tuesday, April $17^{\text {th }}$, the last day of work.

\section{The Internship Evaluation Form}

Sample data from the internship Evaluation form is illustrated below without identifying firms or individuals (see Figure 7). Of the sixty-five intern employed during spring 2007, 46 (71\%) of them report that they received an offer of full-time employment from their internship employers and were leaning toward accepting the position. 
Figure 7

Partial Sample of Internship Evaluation Form

\begin{tabular}{|c|c|c|c|c|c|c|c|c|c|c|c|c|}
\hline $\begin{array}{c}\text { Ovrtm } \\
\text { Hrs } \\
\end{array}$ & $\begin{array}{c}\text { Total } \\
\text { Hrs }\end{array}$ & Audit & $\begin{array}{l}\text { Inc } \\
\text { Tax } \\
\end{array}$ & Cost & G/L & $\begin{array}{c}\text { Prop } \\
\text { Tax } \\
\end{array}$ & Fin $\mathbf{S t}$ & $\begin{array}{c}\text { Int } \\
\text { Audit } \\
\end{array}$ & Train & Other & $\underset{* *}{\text { Offer }}$ & $\underset{* * *}{\mathbf{A c c e p t}}$ \\
\hline 50 & 560 & & $38 \%$ & & & $2 \%$ & & & $10 \%$ & $50 \%$ & $\mathrm{Y}$ & $\mathrm{Y}$ \\
\hline 100 & 600 & $45 \%$ & $45 \%$ & & & & & & $5 \%$ & $5 \%$ & $\mathrm{Y}$ & Y \\
\hline 250 & 810 & $40 \%$ & $50 \%$ & & & $5 \%$ & & & $5 \%$ & & $\mathrm{Y}$ & $\mathrm{Y}$ \\
\hline 0 & 480 & $80 \%$ & & & & & & & $20 \%$ & & $\mathrm{Y}$ & $\mathrm{Y}$ \\
\hline 50 & 650 & $5 \%$ & $80 \%$ & & & & $5 \%$ & & $5 \%$ & & $\mathrm{Y}$ & $\mathrm{Y}$ \\
\hline 100 & 700 & $10 \%$ & $75 \%$ & & & $10 \%$ & & & $5 \%$ & & $\mathrm{~N}$ & $\mathrm{Y}$ \\
\hline
\end{tabular}

\section{Employers}

Firm Evaluation of the Process

Over ninety percent of employers agree or strongly agree (see Figure 8) that the Career Center was organized and helpful in scheduling (91\%) and students were well prepared for interviews (96\%). While eightyseven percent of employees found the on-campus interview process met their needs.

Ninety-six percent of employers agreed or strongly agreed (see Figure 9) that communication with the internship director was sufficient to meet their needs. Seventy percent of employers thought the matching process was an efficient method to place interns. Twenty five percent of employers are neutral about the matching process.

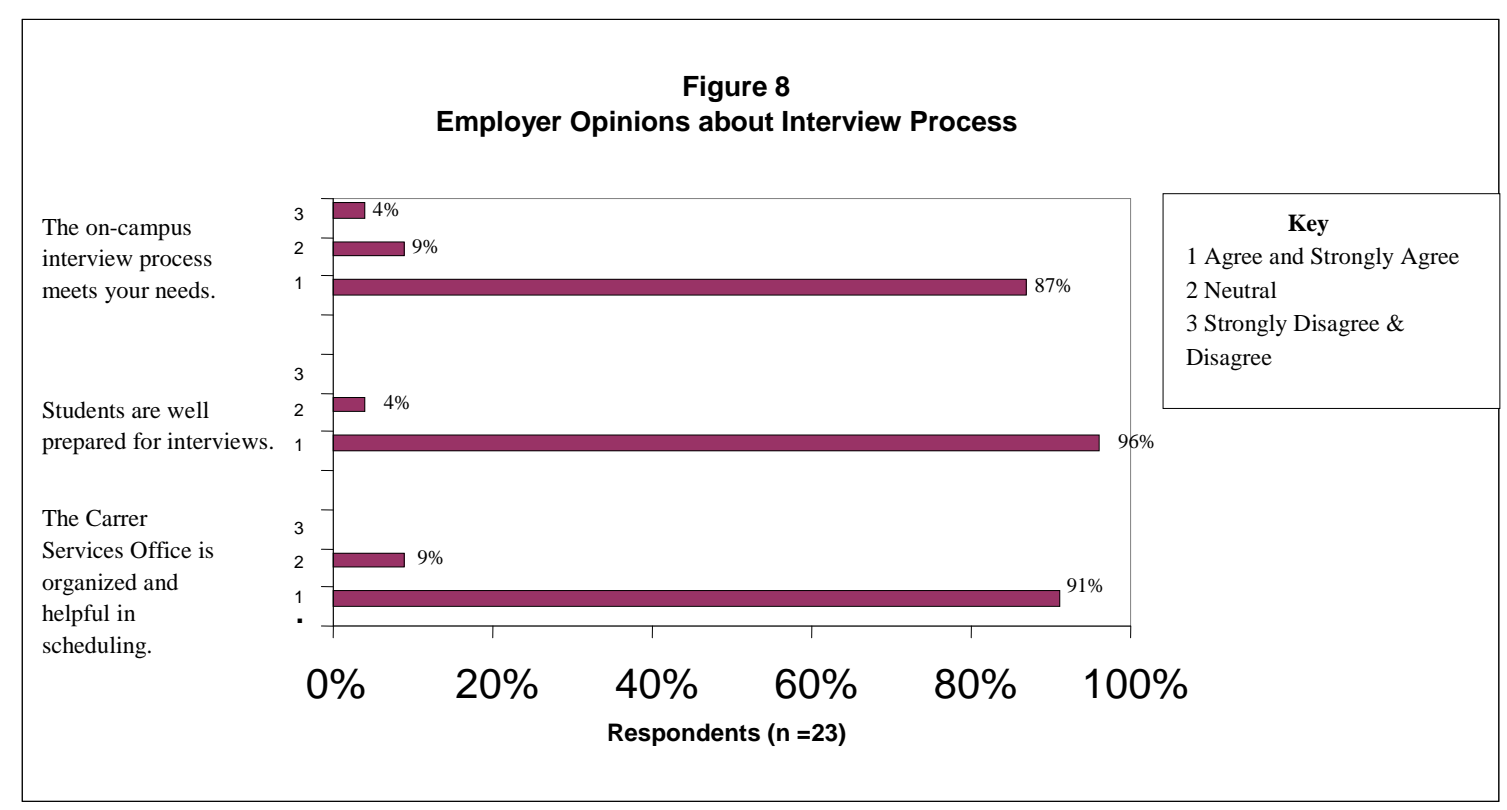




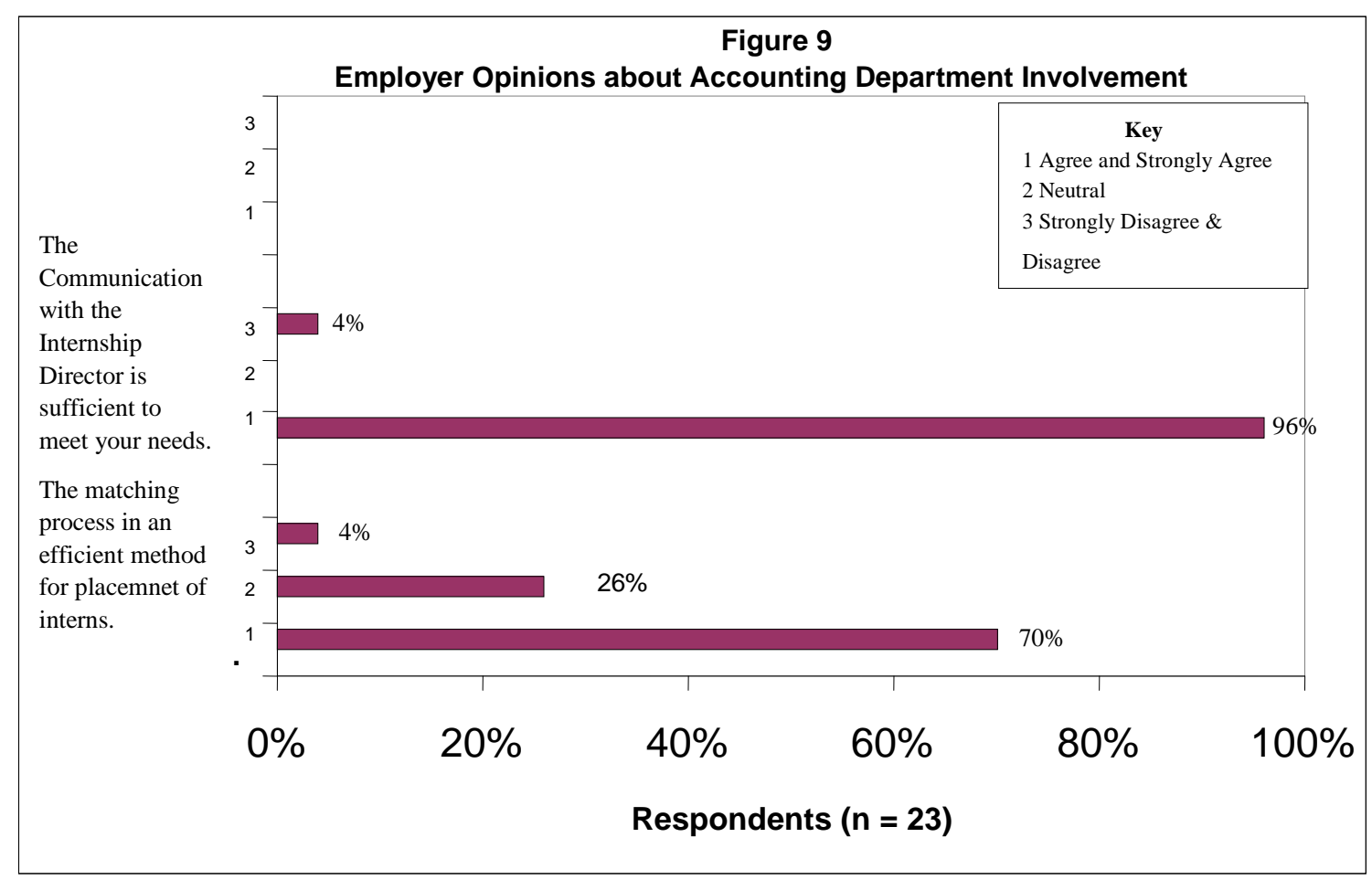

\section{Firm Evaluation Of Interns}

Employers evaluated the student intern by using the Employer Accounting Internship Evaluation Form (see Figure 5). Specifically employers are asked if the student intern met (score of 2) or exceeded (score of 3) their expectations for the following eight criteria UW-Whitewater data for spring 2007 is presented in Figure 10. The results below indicate that overall interns exceeded employer expectations in all categories except written communication skills.

Figure 10

Employers Evaluation of Interns (UWW- Spring 2007)

$(\mathbf{n}=\mathbf{5 1})$

\begin{tabular}{|c|c|c|}
\hline Statements & & Average Score \\
\hline 1 & Accounting Knowledge/Technical Skills & 2.19 \\
\hline 2 & Computer Knowledge/Technical Skills & 2.24 \\
\hline 3 & Oral Communication Skills & 2.29 \\
\hline 4 & Written Communication Skills & 1.94 \\
\hline 5 & Ability To Work Well With Others & 2.52 \\
\hline 6 & Dependability & 2.50 \\
\hline 7 & Organizational Skills & 2.31 \\
\hline 8 & General Business Knowledge & 2.08 \\
\hline
\end{tabular}




\section{Employer Match Effectiveness}

For the spring 2007 semester students were placed with their first employer choice sixty-eight percent of the time. Students were placed with their first or second employer choice over eighty percent of the time (see Figure 11). Firms received their top intern choice sixty percent of the time. They received their top choice or next level strong choice over eighty-eight percent of the time (see Figure 12).

Figure 11

Match Effectiveness- Student

UW-W- Spring 2007

\begin{tabular}{|c|c|c|c|}
\hline Cum \% & \% & $\#$ & Employer Preference \\
\hline $68 \%$ & $67.74 \%$ & 42 & First \\
\hline $80.65 \%$ & $12.90 \%$ & 8 & Second \\
\hline $100.00 \%$ & $19.35 \%$ & 12 & Other \\
\hline
\end{tabular}

Figure 12

Match Effectiveness- Firm

UW-W- Spring 2007

\begin{tabular}{|c|c|c|c|}
\hline Cum \% & \% & $\#$ & Student Preference \\
\hline $60 \%$ & $59.68 \%$ & 37 & Top \\
\hline $88.71 \%$ & $29.03 \%$ & 18 & Strong \\
\hline $100.00 \%$ & $11.29 \%$ & 7 & Accept. \\
\hline
\end{tabular}

\section{DISCUSSION AND CONCLUSIONS}

The battle for talent is being fought when employers are hiring interns. In the spring semester of 2007 , seventy-one percent of our interns received a full-time job offer after graduation and were leaning toward accepting that job offer. Accounting educators should consider what type of internship process will provide the best method to provide as many students as possible with internships that can lead toward full time employment.

This paper presented a model where the student comes first. In essences the student gets to choose the firm for their internship. This process allows firms and students a full exposure to available opportunities. While students develop research and interview skills, firms also get feedback on how well they are recruiting and attracting new talent.

The internship coordinator matches students and employers based on the students choice. The spring semester of 2007 found that more than eighty percent of the students received their first or second internship choice while employers received their top or strong choice intern candidate more than eighty-eight percent of the time. This can create a win-win situation for employers and students who compete on a level playing field for future accounting positions.

\section{ACKNOWLEDGEMENT}

We would like to thank Ann O'Brien, University of Wisconsin-Madison, for her collaboration with us about the accounting internship program at her institution. 


\section{REFERENCES}

1. Albrecht, W. S., \& Sack, R. J. (2000). Accounting Education: Charting the course through a perilous future. Sarasota, FL:American Accounting Association.

2. (2005). Building University Relations is a Slow Race with Big Rewards, CPA Practice Management Forum, 1(12) 1.

3. English, D. M. \& Koeppen, D. R. (1993) The Relationship of Accounting Internships and Subsequent Academic Performance. Issues in Accounting Education, 8 (2), 292 - 299.

4. Knechel, W. R. \& Snowball, D. (1987). Accounting Internships and Subsequent Academic Performance: An Empirical Study. The Accounting Review, 62(4), 799-807.

5. Lauber, C. A., Ruh, L.,Theuri, P. M. \& Woodlock, P. (2004). Road to the Future, Journal of Accountancy, 198 (1) 41-47.

6. $\quad$ Schmutte, J. (1985). Student Internships: A Valuable Recruiting Tool. The CPA Journal, 55(9), 83 -86.

7. Siegel, P. H. \& Rigsby, J. T. (1988) The Relationship of Accounting Internships and Subsequent Professional Performance. Issues in Accounting Education, 88 (3), 423-432.

8. $\quad$ Spolsky, J. (2007). Recruiting the Top 1 Percent. Inc. 29(5), 81-82.

9. Thilmany, J. (2007). Quick Studies. HR Magazine, 52(5), 68-72.

\section{NOTES}

